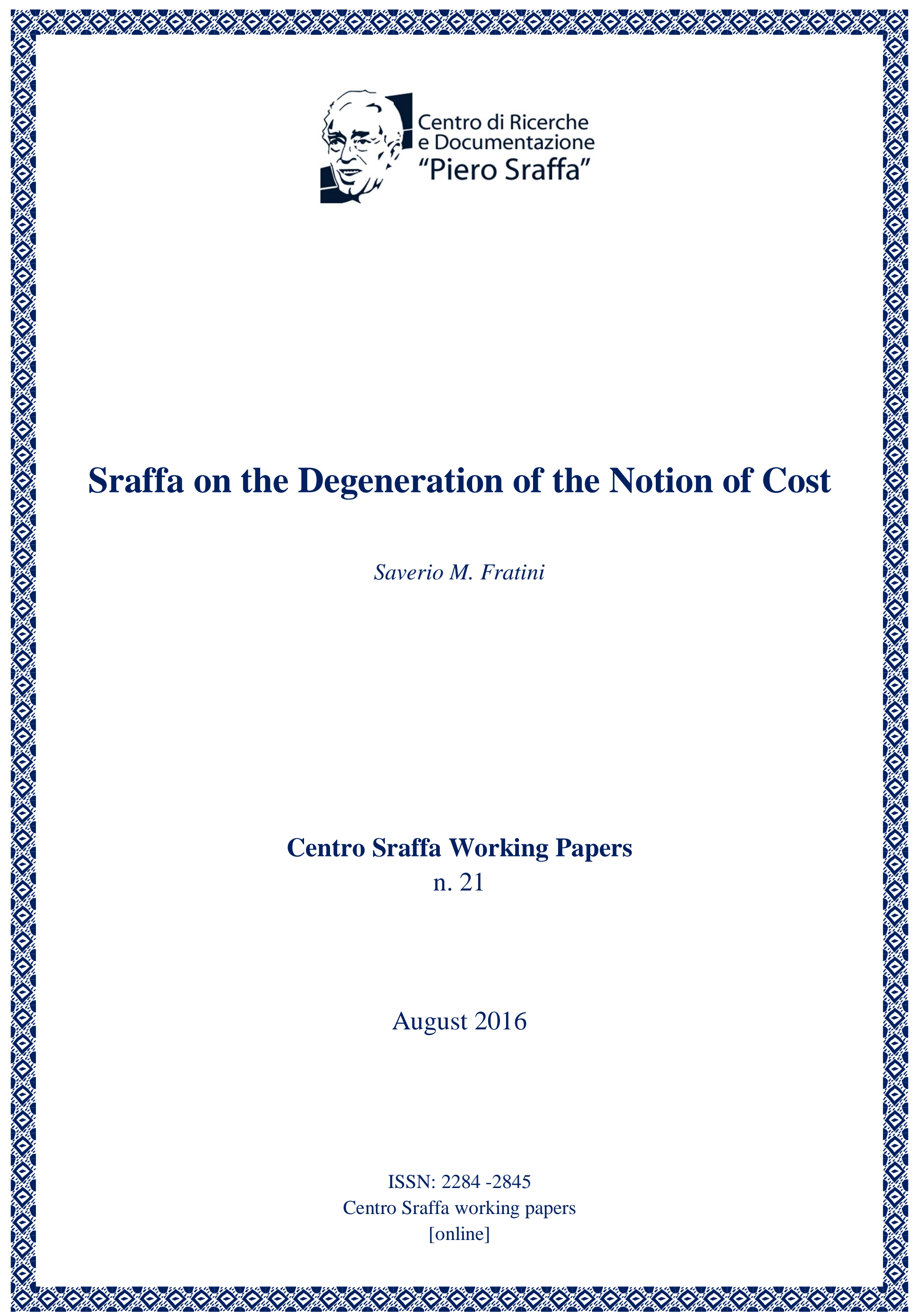




\title{
Sraffa on the Degeneration of the Notion of Cost
}

\author{
Saverio M. Fratini \\ Università Roma Tre
}

\begin{abstract}
The paper reconstructs the history of what Sraffa called the 'degeneration of cost' as emerges from his manuscripts of the late 1920s. In particular, Sraffa regards the Physiocrats as having the correct idea of cost as being the commodities that allow workers to subsist. The classical economists measured this bundle of commodities in terms of labour, which they also ambiguously viewed as 'toil and trouble'. Then, the idea of labour as 'toil and trouble' was indicated by neoclassical authors as an anticipation of their conception of cost as a sacrifice. Conferring also upon abstinence from consumption the nature of sacrifice, the neoclassical-marginalist theory understood wages and interest as compensation for the disutility of working and saving. Then, cost was ultimately seen as what induces workers and capitalists to produce. This completed the degeneration of cost from the objective-physical conception of the Physiocrats to the subjective-psychological view of the neoclassical school.
\end{abstract}

Keywords: cost; economic methodology; Sraffa; Sraffa's manuscripts

JEL codes: B12; B13; B41; B51; D24

\section{Introduction}

According to the reconstruction provided by Garegnani in his seminal essay on Sraffa's unpublished manuscripts, ${ }^{1}$ until the first half of 1927 Sraffa essentially accepted Marshall's approach to the theory of value. It was during the summer of 1927, while preparing the lectures delivered at Cambridge over the period 1928-31, that he began to drift away from the partial equilibrium method and to explore the difficulties that arise for the determination of the prices of many commodities and factors together.

As will be shown in section 2, in order to tackle these difficulties, Sraffa started to look for an 'ultimate standard' for the value of commodities. Specifically, the attempt was to refer to one of the two standards discussed by Marshall, namely the real cost, but

\footnotetext{
${ }^{1}$ Garegnani (2005).
} 
conceiving it in terms of commodities, as a 'physical real cost', ${ }^{2}$ rather than in terms of 'efforts and sacrifices' (disutility), as instead Marshall did. ${ }^{3}$

Bearing in mind that cost must be conceived as the commodities necessary to enable production, Sraffa discovered that Petty and the Physiocrats had this 'right notion of cost', which he then called 'physical cost' ${ }^{4}$ This discovery led him, during the period from Autumn 1927 to Spring 1928, to undertake the reconstruction of the history of the 'degeneration of cost' from the initial 'right' conception to those of Marshall and the other neoclassical authors, highlighting the fundamental steps of this path. ${ }^{5}$ Sraffa wrote as follows in a well-known manuscript:

Evolution of concept of cost.

It was only Petty \& the Physiocrats who had the right notion of cost as "the loaf of bread". Then somebody started measuring it in labour, as every day's labour requires the same amount of food.

Then they proceeded to regard cost as actually an amount of labour. Then A. Smith interpreted labour as "the toil and trouble" which is the "real cost" (Ricardo, p. 10, 15 n) ${ }^{6}$ and the "hardship".

Then this was by Ricardo brought back to labour, but not far back enough, and Marx went only as back as Ricardo.

Then Senior invented Abstinence, and Cairnes unified all the costs (work, abstinence $\&$ risk) as sacrifice.

Now Davenport, Cassell, Henderson, have carried it a step further, the last step in the wrong direction. (D3/12/4:4)

And, following Sraffa, this is the story we shall try to tell in sections 3, 4, 5 and 6.

Moreover, section 7 will be devoted to Sraffa's comparison between the notion of physical cost and that adopted by the neoclassical theory, which he named 'psychic cost'. Furthermore, some of the reasons leading the degeneration from the former conception to the latter will be considered in section 8 .

\footnotetext{
${ }^{2}$ The list of papers in which it is claimed that 'between 1927 and 1928 Sraffa introduced, or at least went much more deeply into, the notion of "physical real cost"" (de Vivo 2001, p. 158) includes: de Vivo (2001), Garegnani (2004) and (2005), Kurz (1998), (2003) and (2006), Kurz and Salvadori (2005) and (2006), Marcuzzo (2001), Pasinetti (2001).

${ }^{3}$ According to Marshall:

The exertions of all the different kinds of labour that are directly or indirectly involved in making it; together with the abstinences or rather the waitings required for saving the capital used in making it: all these efforts and sacrifices together will be called the real cost of production of the commodity. The sums of money that have to be paid for these efforts and sacrifices will be called either its money cost of production, or, for shortness, its expenses of production; they are the prices which have to be paid in order to call forth an adequate supply of the efforts and waitings that are required for making it; or, in other words, they are its supply price' (Marshall 1920, p. 339, V, iii, 2, emphasis original).

${ }^{4}$ In actual fact, Sraffa used the expression 'physical real cost' mainly in the manuscripts in the folder D3/12/3, the so-called pre-lectures, written during the Summer of 1927 and entitled 'Physical real costs'. This expression, however, became much rarer in Sraffa's manuscripts as from November 1927, being replaced simply by 'physical cost'. It is not easy to grasp whether this change of expression corresponded to a change of contents, although 'physical real cost' seems to allude to the possibility of representing Marshall's real cost in terms of commodities rather than of disutilities, whereas 'physical cost' appears more general and detached from Marshall's analysis. Cf. also section 2.

${ }^{5}$ This reconstruction was then also used by Sraffa in his lectures. Cf. Signorino (2005, pp. 372-376).

${ }^{6}$ The page numbers refer to Ricardo (1888).
} 
Finally, the paper is based on the analysis which emerges from Sraffa's manuscripts referable to the period from Summer 1927 to the end of $1928 .^{7}$ Some of these manuscripts have been quoted and discussed repeatedly in various essays, ${ }^{8}$ we believe nonetheless that the picture we shall outline here by means of them can present elements of novelty.

\section{The conception of physical cost}

In order to reconstruct the path which led Sraffa toward the conception of physical cost, we must start from Marshall's partial equilibrium approach to the theory of value, which, as is widely recognized, ${ }^{9}$ Sraffa essentially accepted in his articles of 1925 and 1926.

It is a fact that the demand-and-supply apparatus was presented by Marshall as an attempt of synthesis between the position of Jevons, who had maintained that value depends entirely upon marginal utility, and the one attributed to Ricardo and J.S. Mill, according to which value is determined by cost of production. ${ }^{10}$ In Marshall's theory, instead, the 'cost of production principle' and the 'final utility principle' are regarded as component parts of 'one all-ruling law of supply and demand. ${ }^{11}$ For every possible given quantity of a commodity, the cost of production and the marginal utility have their money counterpart, respectively, in the supply price (or the expenses of production) and the demand price. It is only via their equality that the value of that commodity is determined, together with its equilibrium quantity.

Moreover, as Marshall had explicitly claimed (1920, p. 463, V, xiii, 2), 'the normal price of a commodity which obeys the law of constant return is determined absolutely by its expenses of production: demand has no influence in the matter beyond this, that the thing will not be produced at all unless there is some demand for it at this fixed price'. Therefore, since constant returns to scale - or constant average costs - had to be assumed in order to avoid the problems Sraffa himself had highlighted in his articles, the cost of production appeared, in this framework, to be the only determinant of commodity prices. ${ }^{12}$

\footnotetext{
${ }^{7}$ While most of the documents considered here are not individually dated, there is nearly always a reference to a period of time (months, seasons or university terms and the year) on the folder.

${ }^{8}$ Some of these essays are listed in footnote 2. For brevity, hereafter we shall not specify for each document whether or not it has already been quoted in other papers.

${ }^{9}$ Cf. in particular Garegnani (2005, p. 455-458).

${ }^{10}$ For an in depth reconstruction of the debate about the 'ultimate standard of value' and the role of Marshall's theory with reference to it, see Campus (2000).

11 "The "cost of production principle" and the "final utility" principle are undoubtedly component parts of the one all-ruling law of supply and demand; each may be compared to one blade of a pair of scissors. When one blade is held still, and the cutting is effected by moving the other, we may say with careless brevity that the cutting is done by the second; but the statement is not one to be made formally, and defended deliberately' (Marshal 1920, p. 820, App. I, 3).

${ }^{12}$ Cf. Sraffa (1926, p. 541).
} 
It was with this theory in mind that Sraffa started preparing the lectures he would then deliver at Cambridge over the period 1928-31. We refer here to the group of manuscripts called pre-lectures and referable to the summer of 1927 (folder D3/12/3).

However, it was precisely in preparing the lectures that Sraffa began to move away from this approach. In particular, he became aware that the reasoning leading to the determination of commodity prices by their expenses of production 'is legitimate only in respect of one commodity at a time: we could of course apply it in succession to each of the other commodities ... but not to all or several commodities at the same time', as he wrote in the manuscript below.

We shall mainly be concerned with the study of the causes of the determination of the price of an individual commodity, considered separately from all the others; we shall assume that all prices and quantities of other commodities are constant (i.e. not affected by variations of our own), and regard them as data of our problem. ${ }^{13} \mathrm{We}$ shall therefore take into consideration only demand prices and expenses of production, without regard of the utilities and real costs which may be behind them. ${ }^{14}$ It would not be legitimate, under the given hypotheses, to follow a different course: in fact, the only way of measuring the utilities of our commodity, is to observe the amount of money sacrifice that each successive dose is able to call forth and, being a very specialised commodity, the slope of the demand curve for it will be chiefly determined by the prices of substitutes (at fixed prices) and by their efficiency in giving utility, and only to a negligible extent by its «absolute utility»: ${ }^{15}$ and we shall not be able to go behind the prices of substitutes to find out their utility, as, ex hypothesis, we cannot make vary their consumption. ${ }^{16}$

On the other hand, cost of production would be only the loss of remuneration \{ of production factors $\}$ involved in not using them (at fixed remuneration) in the other industries, which would, ex hypothesi, be willing to take any amount of them at fixed prices. $^{17}$

But this method of reasoning is legitimate only in respect of one commodity at a time: we could of course apply it in succession to each of the other commodities (so far as they can reasonably be brought within such hypotheses: not, e.g., corn) but not to all or several commodities at the same time.

13 \{Sraffa's note: \} We shall also assume that our commodity is only one of a great number that is produced with the same factors of production and consumed by the same consumers, so that its variations cannot appreciably affect marginal utility of money and cost of factors of production.

${ }^{14}$ \{ Sraffa's note: $\}$ expand according to Marshall 338-9.

15 In this passage, Sraffa's reference to 'a very specialized commodity' seems to require at least a brief attempt at interpretation. There are several possible ways to understand commodities in economic analysis. In particular, we can make reference to the different needs the consumption goods satisfy and call these goods "cloths", "food" or "housing", as is typically done within first year Microeconomic textbooks. However, if we want to adopt the partial equilibrium method, we cannot use this way of conceiving commodities. In the partial equilibrium approach each sector or market must be small enough to have negligible influence on the other sectors of the economy. Accordingly, we cannot refer the analysis to "cloths" or "food", but rather to specific items like "cotton t-shirts" or "basmati rice".

Therefore, as Sraffa stressed, the demand for a very specific commodity like "basmati rice" does not depend on its "absolute utility". The absolute need for basmati rice can even be difficult to conceive: human beings do not need exactly this particular kind of rice, they need nourishment, and that can be obtained by means of every sort of food.

16 Sraffa's note:\} Demand curves are inter-destructive: Wicksteed.

17 Sraffa's note: \} expand explain why it is necessary to stick very rigidly to the hypotheses. 
We can therefore go without a conception of ultimate standard of value: our standard is - the value of other commodities: and this can be done, and is useful so far as we want to inquire into the internal organisation of an industry and its methods of marketing.

But so soon as we want to analyse how the general equilibrium is reached - i.e. we want to analyse the interactions of one commodity upon the other, how they affect each other's conditions of production and utilities, and how the remuneration of common factors of production is determined - then an ultimate standard of value is required. We can no more refer the costs and utilities of one article to the costs and utilities of another one - in this case this would beg the question, and we would be reasoning in a circle.

Two standards offered: they are the same thing - words. But the intermediate is illegitimate: you cannot say where one begins and the other ends: and they are not independent. And if they were could they be measured one in terms of the other? crossing curves, Bernoulli? or Wicksteed

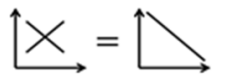

However there is one reality in cost, i.e. labour. (Clay) (D3/12/3:37-40, emphasis in the original)

Summing up, according to Sraffa, the possibility of determining commodity prices without specific reference to an 'ultimate standard of value' (utility or cost) is a consequence of the partial equilibrium approach. In that approach, in fact, the marginal utility of a commodity is actually measured by the money sacrifice which its last dose is able to call for, while its cost of production is based on the remuneration that the factors used would have received if employed in other sectors. Therefore, demand and supply prices for an individual commodity are determined on the basis of the prices of other commodities and factor remunerations, which are taken as data. But in order to determine the prices of all commodities together, Sraffa, at that time, felt the need to refer value to an ultimate standard, so as to avoid the risk of arguing in a circle, which he was worried about because of the connections among commodity prices, as well as between commodity prices and factor remunerations. ${ }^{18}$ However, in Sraffa's opinion, if the two standards Marshall considered in his analysis, namely the marginal or final utility and the real cost, are not expressed in terms of demand price and expenses of production, they are just words. And the synthesis of the two that Marshall provided by the law of supply and demand is 'illegitimate', because supply and demand, in the general equilibrium framework, are not independent. ${ }^{19}$

\footnotetext{
${ }^{18}$ Commenting on a passage from Quesnay’s Dialogues quoted by Cannan (1893), Sraffa wrote: Quesnay, quoted by Cannan, Theories, 20

"la valeur réale de ces marchandises n'est que la valeur même de la matière première et de la subsistance que l'ouvrier a consommée pendant son travail"'

The second valeur is obviously misplaced and transforms the whole argument in a vicious circle. (D3/12/11:73, emphasis in the original).

${ }^{19}$ The problem of the lack of independence of demand and supply curves is considered by Sraffa also in another document in the same folder:

If we assume, as it is correct in general, that in our commodity's production are used only factors in «general» use, it is clear that the conditions of supply and demand of this commodity will not (appreciably) affect the reward (price) of factors. In fact, we are considering only small changes: a small change in one of many commodities could not affect factors' price (second order). If it affected them, all prices would change, our
} 
Moreover, as for the ultimate standards of value discussed by marginalist authors, ${ }^{20}$ and the real $\operatorname{cost}^{21}$ in particular, Sraffa notes that:

All the ultimate standards we have considered up to this point are psychological: that is to say their test is the willingness of consumers or producers to make a sacrifice in order to obtain a utility - or vice versa. Real costs interpreted as disutility are thus strictly dependent upon the alternative uses to which they can be put: the more attractive such alternative uses, the greater the disutility incurred in giving them up. But this is still, it may be said, a relative, not an ultimate, conception. (D3/12/3:42, emphasis in the original).

Accordingly, Sraffa began to look for a standard of value other than utility or real cost/disutility, and started considering the possibility of a 'physical real cost', namely a sort of Marshall's real cost but expressed in terms of commodities rather than 'efforts and sacrifices', i.e. disutility. Although he believed that some difficulties could arise because of the substitutability concerning primarily the goods consumed by workers, the idea was, initially, to find a 'necessary commodity' involved in every production and in terms of which the cost of all the other commodities could be reduced. He thought that:

if commodities have substitutes, there is no more "one" real cost composed of a series of various quantities of commodities, which don't require a common measure: so soon as there are substitutes, there is an infinite number of combinations of the different commodities, which satisfy the condition of maintaining life and efficiency of the producers. ${ }^{22}$ How are we to choose between these combinations? it is of course impossible to choose between $1 \mathrm{~kg}$ of bread $+1 / 2 \mathrm{~kg}$ of meat and $1 / 4 \mathrm{~kg}$ of bread $+1 \mathrm{~kg}$ of meat, unless we introduce the common measure of their value - and that would beg the question.

It should be remarked that if this difficulty (of no substitutes) were overcome and an absolutely necessary commodity found, the difficulty of reducing to a common measure the various things entering into real cost would solve by itself. In effect, would be easy to find the cost of all the other things in terms of the necessary one, and thus by going back enough in the genealogy of production (and stopping along each branch so soon as we have resolved it into our necessary commodity) we might find exactly the total amount of corn (if this were the ideal necessary commodity, which it is not) that has actually entered into the production of, say, this book, and covers entirely its cost of production, at the exclusion of any other commodity. (D3/12/3:44-45)

Moreover, referring to the necessary commodity to be used as 'a common measure' of 'the various things entering into real cost,' Sraffa stressed that ' $[\mathrm{t}]$ he best measure

demand curve would be modified - therefore this would mean that $\mathrm{D}\{$ emand $\} \mathrm{C}\{\mathrm{urve}\}$ is not independent of $\mathrm{S}\{$ upply\} C $\{$ urve $\}$, and all our static system would collapse. (D3/12/3:60)

${ }^{20} \mathrm{Cf}$., amongst others, Clark (1893) and Böhm-Bawerk (1894).

${ }^{21}$ That the real cost of a commodity depends on the prices of the other products was clearly stated by Henderson, who Sraffa referred to in many manuscripts of that period. Henderson (1921, pp. 164-165) maintained that the real cost of a commodity corresponds to the loss of utility which arises from the fact that a smaller quantity of the other commodities is produced and consumed in order to make the inputs available for the production of the commodity in question.

22 \{Sraffa's note:\} But in a community that produces just what is sufficient to keep it going would there not be only one combination which satisfies the above condition? it would be "the cheapest". 
available is the amount of various commodities that is required to support during an hour, a common average labourer' (D3/12/3:46).

This is the state in which Sraffa left the topic in the group of manuscripts called prelectures. During the later months of the same year he went on developing the idea of cost as a set of commodities, namely 'the means necessary to enable production to be made' (D3/12/4:7, emphasis in the original), and referred to it as 'physical cost'. In particular, between the end of 1927 and the beginning of 1928, Sraffa's studies proceeded in two main directions. On the one hand, he tried, by means of examples, to find a way to determine commodity exchange values on the basis of their physical costs, i.e. their methods of production. On the other hand, he performed a reconstruction, both historical and analytical, of the process toward which the notion of 'physical cost', expressed in terms of the commodities which support an average labourer, that he attributed to Petty and the Physiocrats, degenerated into the modern notions of cost. The next sections will be devoted to this second direction followed by Sraffa.

\section{From food to labour}

In the pre-lectures, Sraffa expressed the idea that cost consists of a set of different commodities, but if this set of commodities is not fixed due to substitutability, then it must be expressed in terms of a 'necessary commodity' and in particular in terms of the composite commodity made with what is necessary to support an average labourer for a given working time.

In these months Sraffa also discovered - probably through reading Marx's Histoire ${ }^{23}$ - that Petty and the French Physiocrats, in their analyses, understood cost in terms of the necessaries required to support the workers. In a document of November 1927 Sraffa hand copied the following note from Marx's Histoire:

Petty, Pol\{itical\} Anat \{omy\} of Ireland, London 1672, p. 65

(quot $\{$ ed $\}$ by Marx, Hist $\{$ oire $\}$ I, 3 n.)

"C'est la nourriture journalière moyenne d'un adulte et non pas son travail journalier, qui est la mesure ordinaire de la valeur ... C'est pourquoi j'ai fixé la valeur d'une hutte irlandaise d'après le nombre des rations journalières consommées par l'ouvrier pendant la construction" e Marx commenta "C'est bien la théorie des physiocrates" (D3/12/11:88, emphasis in the original). ${ }^{24}$

Therefore, Petty and the Physiocrats 'had the right notion of cost as "the loaf of bread". The process of tranformation of this notion began very early, however, with the measurement of the cost in terms of labour, instead of subsistences:

\footnotetext{
${ }^{23}$ As is known, the English translation of Marx's Theorien über den Mehrwert was not available at that time and Sraffa studied the (1924) French edition.

24 'The days food of an adult Man, at a Medium, and not the days labour, is the common measure of Value, and seems to be as regular and constant as the value of fine Silver... Wherefore I valued an Irish Gabbin at the number of days food, which the Maker spent in building of it' (Marx [1863] 1963, vol. I, p. $362)$.
} 
All trouble seems to have been caused by small initial errors, which have cumulated in deductions (e.g. food of worker $=$ quantity of labour, is nearly true. Petty had foreseen the possibility of being misunderstood, cfr. Marx, Hist\{oire\}, vol I, p. 1 (D3/12/11:32, emphasis in the original).

According to Sraffa, the classical economists knew that the cost of production (and hence the value) of each commodity depends on the amount of commodities which have been destroyed for its production, ${ }^{25}$ but in order to express this cost as a single magnitude they conceived it as an amount of labour. Nonetheless, the equality 'food of worker = quantity of labour' was deemed by Sraffa as 'nearly true', so that although 'Smith, Ricardo and Marx indeed began to corrupt the old idea of cost, from food to labour', 'their notion was still near enough to be in many cases equivalent' to the idea of cost of Petty and the Physiocrats (cf. D3/12/4:2). ${ }^{26}$

Sraffa did not explicitly specify the way the 'nearly true' equality 'food of worker = quantity of labour' has to be understood. However, he appears to have in mind the following argument: the amount of food that the production of a unit of a commodity requires $^{27}$ depends on both the quantity of labour (directly and indirectly) employed to produce it and the amount of necessaries which support a labourer (on average) for a working day. If this bundle of commodities is given because 'every day's labour requires the same amount of food' (D3/12/4:4), then the cost of a commodity in terms of workers' subsistences is equivalent to the quantity of labour it embodies. ${ }^{28}$ In other words, once the composite commodity which supports a worker for a day is defined, the cost of a certain output can be understood as a quantity of this composite commodity, which is numerically tantamount to the quantity of labour embodied in that output.

Although the quantity of labour used in order to measure the cost is equivalent to the amount of subsistences forming the physical cost, the passage from food to labour was

${ }^{25}$ As for Torrens, Sraffa wrote that:

Torrens knew that the (absolute) value of the product is determined by (in fact, $\underline{\text { is}}$ ) the amount of things that have been destroyed for its production. But he did not see his way through without finding a "common measure" of them: he probably felt a repulsion to, or thought that it could not be done, to sum together quantities of heterogeneous things measured in different units. This was of course fatal: he started to find something common in them, upon which to base his measurement: the labour theory was ready at hand, all those things had been "made by labour", and he therefore regarded them simply as quantities of "accumulated labour". The result was of course absurd. He proceeded to say that the "exchangeable value" was determined entirely by "the amount of capital, or quantity of accumulated labour, and not the sum of accumulated and immediate labour expended on production" (D3/12/5:26, emphasis in the original).

${ }^{26}$ A similar idea can be found in Sraffa's lectures (D2/4), when he wrote that:

there are in A. Smith's doctrine two distinct ways of representing cost of production: as amount of labour, of a "toil and trouble" required for producing a commodity, or as a stock of material goods, which are used mainly for supporting that labour. The two quantities cannot of course be added together, without duplication, since they represent, not simultaneous distinct objects, but successive phases of the same quantities. But A. Smith, regarding the quantity of labour as proportional to the quantity of goods consumed for its maintenance, could for many purposes treat the two quantities as equivalent.

${ }^{27}$ According to Sraffa's idea of the reduction of the physical cost to a necessary commodity mentioned at the end of section 2, such an amount of food includes not only the subsistence for the labour directly employed, but also the food for the workers that produced the means of production, and the means of production of the means of production, and so on.

${ }^{28}$ On the equivalence between a quantity of food and a quantity of labour, Sraffa also quotes Feuerbach's well-known remark, 'Man is what he eats' ('der Mensch ist was er isst') (D3/12/10:40). 
the premise for both the confusion about the conception of labour treated in the next section, and the real degeneration of the notion of cost that occurred as a result of conceiving it as a sum of efforts and sacrifices (section 5).

\section{The 'mystical conception' of labour}

In section 2 we referred to Marshall's attempt to arrive at a synthesis, or an actual reconciliation, between Jevons' standpoint, in which utility is the ultimate determinant of value, and the one that Jevons himself attributed to the 'Ricardo-Mill school', according to which value depends upon the cost. This was, at least, Marshall's reconstruction. In fact, the position that Jevons and other marginalist authors explicitly attributed to Ricardo and Mill and intended to disprove, was the one in which labour is regarded as the 'origin of value'. As Jevons wrote:

Repeated reflection and inquiry have led me to the somewhat novel opinion, that value depends entirely upon utility. Prevailing opinions make labour rather than utility the origin of value; and there are even those who distinctly assert that labour is the cause of value. I show, on the contrary, that we have only to trace out carefully the natural laws of the variation of utility [...] in order to arrive at a satisfactory theory of exchange (Jevons 1888: pp. 1, 2, emphasis in the original).

Therefore, the early neoclassical economists, and Jevons in particular, believed that the scholars belonging to the 'Ricardo-Mill school' had asserted that labour is the origin or even the cause of value. ${ }^{29}$ This distorted interpretation of the labour theory of value is actually known to be one of the arguments of the Ricardian socialists. They claimed that 'if labour produces all wealth, then labour should receive all wealth. ${ }^{30}$ Hence, Jevons and the others who maintained that utility, and not labour, is the ultimate determinant of value intended, in this way, to contrast the socialist view. ${ }^{31}$

Coming back to Sraffa, as we saw in the previous section, he thought that the classical economists adopted labour essentially as a measure of the physical cost. Moreover, as will be made clear in section 8, Sraffa was well aware that the political implications of the classical approach to distribution do not rest on the labour theory of

\footnotetext{
29 Actually, Ricardo referred to the labour bestowed on the production of commodities as 'the original source of exchangeable value' (Ricardo 1951-73, vol. 1, p. 13).

${ }^{30}$ In his analysis of the political implications of economic theory, Fetter wrote:

Labor is the source of value (exchange value, virtually market price, as he [Ricardo] used it); labor is the cause of value; labor produces all wealth. Naturally follows the ethical and political conclusion: if labor produces all wealth then labor should receive all wealth.

This conclusion was drawn almost immediately by contemporaries of Ricardo, and while the commonplace McCulloch was striving as a faithful disciple to prove the unqualified truth of the labor-theory against even the admissions of Ricardo himself, "the Ricardian socialists" were drawing radical conclusions from it that in principle completely anticipated the later use of it by Karl Marx (Fetter 1923, 597-8).

Sraffa took the reference to Fetter's (1923) article from Clark's essay in Tugwell (1924). Cf. (D3/12/11:8).

${ }^{31}$ This point will be considered again in section 8 .
} 
value, ${ }^{32}$ but rather on the social surplus and the possibility of its arbitrary division. However, he also recognized that in various passages the classical authors and Marx had an ambiguous position and actually referred to labour not only as the measure of cost, but also as the cause or the source of value. This was, according to Sraffa, a 'mystical' or 'metaphysical' conception of labour. Referring to Marx, he wrote:

The typical case of Marx's metaphysics is his statement that "only human labour produces (causes) values", "values are embodied human energy (crystallised)": there is no doubt that he attached to it some metaphysical meaning (D3/12/4:16).

The classical economists and Marx were prompted to hold this view about labour, according to Sraffa, because conceiving the cost of commodities as commensurate with the amounts of labour employed in their production led them to regard labour as a quantity, although "labour" is the name of the whole process of production' (D3/12/11:32). In Sraffa's words:

It is the whole process of production that must be called "human labour", and thus causes all product and all values. Marx and Ricardo used "labour" in two different senses: the above, and that of one of the factors of production ("hours of labour" or "quantity of labour" has a meaning only in the latter sense).

It is by confusing the two senses that they got mixed up and said that value is proportional to quantity of labour (in second sense) whereas they ought to have said that it is due to human labour (in first sense a non measurable quantity, or rather not a quantity at all) (D3/12/11:64).

On the one hand, understood as a quantity, labour was used by the classical economists to measure the amount of food that constitutes the cost of different commodities. This was just a 'small error', if an error at all. On the other, understood as 'the whole process of production' and therefore not as a quantity, human labour is the source of value. The classical economists and Marx then 'got mixed-up', however, and sometimes regarded the quantity of labour not merely as the measure but also as the determinant of value.

We have seen how Sraffa considered this view as just a 'metaphysical' or 'mystical conception', as emerges from the following manuscript of the spring of 1928 :

\footnotetext{
"Labour"

There appears to be no objective difference between the labour of a wage earner and that of a slave; of a slave and of a horse; of a horse and of a machine; of a machine and of an element of nature (? this does not eat)

It is a purely mystical conception that attributes to human labour a special gift of determining value. Does the capitalist entrepreneur, who is the real "subject" of valuation and exchange, make a great difference whether he employs men or animals? Does the slave-owner? (D3/12/9:89) ${ }^{33}$
}

\footnotetext{
32 Sraffa was also familiar with Marx's critique of Proudhon, who actually held that distorted view of Ricardo's theory of value. Cf. (D3/12/5:36).

${ }^{33}$ The point expressed by Sraffa in this manuscript may be viewed in relation to Marshall's claim that 'free human beings are not brought up to their work on the same principles as a machine, a horse, or a
} 


\section{From labour to sacrifice}

Following Sraffa's reconstruction, the classical economists understood labour as a quantity and used it primarily for the purpose of measuring cost. They did not depart significantly from the views of Petty and the Physiocrats, however, because if the daily necessaries are regarded as a given basket of commodities, an amount of food can be measured by the number of days a worker can subsist on it.

The measurement of cost in terms of labour, although essentially equivalent to the physical cost, was nonetheless misleading. In the previous section we referred to the 'mystical' or 'metaphysical' conception of labour deriving from the confusion between labour as a quantity and as a process. Another ambiguity was related to the way in which Smith and the classical economists understood the amount of labour. On the one hand, they used it as a measure of the necessaries given to workers - an objective quantity - but, on the other hand, they also regarded labour as a sacrifice. ${ }^{34}$ Referring to Ricardo, Sraffa, in the summer 1927, wrote:

Thus to Ricardo's T\{heory of $\} \mathrm{V}\{$ alue\}, based on amount of labour, two interpretations can be given: 1) the subjective (psycholog $\{$ ical $\}$ ), disutility one, 2) the objective (physical), necessaries of existence one. He probably had not always clear in mind the distinction, but I believe that the latter is the one that underlies his $\mathrm{T}\{$ heory of $\}$ $\mathrm{V}\{$ alue $\} .(\mathrm{D} 3 / 12 / 3: 47)^{35}$

As for this possible confusion, '[i]t is A. Smith that shunted the car on the wrong track' (D3/12/11:66). ${ }^{36}$ In expressing this judgment, Sraffa referred in particular (cf. D3/12/4:4) to the well-known passage in the Wealth of Nations (1976, vol. II, p. 47, I.v.2) - which, as Sraffa noted, was quoted with approval by Ricardo too ${ }^{37}$ - where Smith states that 'toil and trouble' is 'what every thing really costs'.

slave' (1920, p. 504). Sraffa comments critically on this passage of Marshall's Principles in D3/12/7:105, which is more or less from the same period as D3/12/9:89, quoted here.

${ }^{34}$ As Marx noted in Capital (cf. Marx 1961-62, vol. I, p. 46), Adam Smith often referred to labour as a 'sacrifice of rest, freedom, and happiness'. Sraffa copied this passage by hand from the French edition of Marx's Capital (cf. Marx 1872-75, p. 61 footnote):

Marx on labour as sacrifice

A. Smith (W \{ealth of $\} \mathrm{N}$ \{ations \} 1, I, V) says: "celui qui travaille ... il faut toujours qu'il donne la même portion de son repos, de sa liberté, de son bonheur". Marx comments: "D' autre coté il pressent, il est vrai, que tout travail n'est qu'une dépense de force humaine de travail, en tant qu'il se représente dans la valeur de la marchandise; mais il comprend cette dépense exclusivement comme abnégation, comme sacrifice de repos, de liberté et de bonheur, et non en même temps comme affirmation normale de la vie. Il est vrai aussi qu'il a en vue le travailleur salarié moderne" (D3/12/10:49, emphasis in the original).

35 As seen in footnote 26, a similar claim is made in Sraffa's lectures (D2/4) with reference to Adam Smith, who, according to Sraffa, represented the cost of production in two distinct ways: i) 'toil and trouble' required for producing a commodity and ii) the stock of commodities supporting the workers.

${ }^{36}$ It is worth noting that this sentence by Sraffa seems to be a sort of paraphrase of a similar judgement Jevons, for opposite reasons, expressed about Ricardo:

When at length a true system of Economics comes to be established, it will be seen that that able but wrongheaded man, David Ricardo, shunted the car of Economic science on to a wrong line, a line, however, on which it was further urged towards confusion by his equally able and wrong-headed admirer, John Stuart Mill. (Jevons 1888 , p. $l)$

${ }^{37}$ Cf. Ricardo (1951-1973), vol. 1, pp.12, 13. 
This passage allowed Marshall, many years later, to indicate Smith as the precursor of the conception of cost as sacrifice or disutility, namely the 'real cost'. Sraffa copied these lines from Marshall's Principles (1920, pp. 758, 759; App. B, 3):

A. Smith's "highest claim to have made an epoch in thought is that he was the first to make a careful and scientific enquiry into the manner in which value measures human motive, on the one side measuring the desire of purchasers to obtain wealth, and on the other the efforts and sacrifices (or "Real Cost of Production") undergone by its producers" (D3/12/11:99, emphasis in the original).

Marshall's reference to Smith concerning the idea of cost in terms of efforts and sacrifices was deemed by Sraffa as a 'futile and misguided' attempt 'to bridge over the cleavage and establish a continuity in the tradition' (D3/12/4:2, note). In fact, according to Sraffa, the change from labour-cost to pain-cost (disutility) was a dramatic breach of the tradition of the classical political economy, so that the neoclassicals had no real forerunner among the classical economists and Marshall tried to force the interpretation of these authors for the purpose of hiding this fact.

A similar attempt was also made by Whitaker, who tried to maintain that a notion of pain-cost was at the basis of the labour theory of value Ricardo adopted: ${ }^{38}$

In the writer's judgement the presumption is that by the labour cost which regulates the exchange value of the commodities, Ricardo meant what we call pain cost. At one place, Ricardo said 'difficulty of attainment' is the true measure of value. It seems almost assured that this must mean 'pain cost'. When cost is conceived as the ultimate essence of value, the cost will almost certainly be pain cost or 'real cost' (Whitaker 1904, p. 137).

Sraffa criticized Whitaker's interpretation of Ricardo's theory very clearly and effectively:

\section{$\underline{\text { Ricardo not pain cost }}$}

$\mathrm{R}\{$ icardo\}'s labour theory of value is based on the assumption that real wages are constant, and fixed at the level of habitual necessaries. The principle of population is always there to see that this constancy is preserved by means of starvation or multiplication. Profits are a percentage of wages (which are the same thing as capital).

Therefore, since price is equal to wages and profits, and the rate of profits is equal in different industries given the number of hours of labour required for each of different commodities, their values will be proportional to the amount of labour embodied in each of them.

This is radically different from pain-cost; the latter assumes freedom of choice and active utilitarian calculation in the worker; hence the necessity of a wage that will compensate the pain he undertakes and will induce him to work: the worker's subjective estimate of his disutility is essential to determine his wages and thus the value of his product. (D3/12/9:31)

For Sraffa, it was therefore very clear that the classical economists, notwithstanding some ambiguity or 'mystical conception' about labour, had no notion of cost in terms of

\footnotetext{
${ }^{38}$ Cf. also D3/12/10:56.
} 
sacrifice or disutility. ${ }^{39}$ On the contrary, as shown in the previous sections, Smith, Ricardo and Marx's notion of cost 'was still near enough to be in many cases equivalent' to that of Petty and the Physiocrats (D3/12/4:2). Despite all that, Marshall and other neoclassical authors tried instead to force the interpretation of some ambiguous passages by Smith and Ricardo for the purpose of attributing a notion of pain-cost to the classical authors, so as to assert an alleged continuity between the old and the new theory. Marshall, as we have already seen in section 2, actually tried to present the latter as the former with the demand side added, that is, as a reconciliation between the position of Jevons and that of the classical economists.

Moreover, once the cost is conceived as 'efforts and sacrifices', then labour is no longer regarded as the only - or at least the major - determinant of cost. In accordance with Senior's theory of abstinence, the sacrifice of capitalists-savers who forego part of their present consumption - i.e. of their present utility - must also be taken into account.

Following Sraffa's reconstruction (see in particular D3/12/4:2 and D3/12/4:4), in the final decades of the 19th century, the founders of the neoclassical theory lumped all the 'efforts and sacrifices' required by the production process, such as labour, abstinence and risk, together as disutility. The 'physical' idea of cost as an amount of 'things' or 'food' adopted by Petty and the Physiocrats thus degenerated into a 'psychological' notion of cost as 'disutility', thereby giving the theory of value a subjective rather than objective basis. In this way, 'the black night descended over P\{olitical\} E\{conomy\}' (D3/12/7:160) and its place was taken by a different science: economics. The differences between the two will be discussed in section 7 , while the next section will be devoted to the critique Sraffa addressed to what at the time he considered the modern theory'.

\section{From sacrifice to inducement}

'The last step in the wrong direction' (D3/12/4:4) was the evolution from the idea of cost as 'sacrifice' to its conception as 'inducement', in other words, from 'pain-cost' to 'opportunity-cost'. The sacrifices involved in working and saving are regarded as foregoing pleasant activities like leisure and consumption, so something must therefore be promised to workers and savers in order to induce them respectively to work and save. In the manuscripts considered here, Sraffa referred to this approach as 'the modern theory of cost' and saw it as due to Cassel, Davenport and Henderson (cf. D3/12/4:4 and D3/12/11:9). He wrote:

A new theory of cost has been advanced in recent years, and finds widespread acceptance. That of alternative cost, or opportunity cost, (Davenport, Cassel, last $\operatorname{ch}\{$ apter $\}$ of Henderson). It is not new in fact: it is only the old 'effort and sacrifice'

\footnotetext{
${ }^{39}$ In the document D3/12/11:10, replying to a sentence taken from Bye (1924) who maintains that the classical economists explained cost in terms of disutility, Sraffa wrote that '[e]ven Mill had no notion of "sacrifice" as cost, let alone the real classics.'
} 
expressed openly. It implies a vicious circle. It confuses the ideas, because more explicitly than the other recognises that disutility is only a loss of utility, and still insists in regarding them as two different things (D3/12/4:5(6)).

According to Sraffa, the idea of workers and capitalists having to be induced to produce hinges on the possibility of them doing something else, of them having alternatives to work and saving, ${ }^{40}$ and "these "alternatives" (the giving up of which constitutes the sacrifice) have to be outside the field of our consideration, or else they involve us in a vicious circle' (D3/12/4:5(2)).

To clarify Sraffa's point, leisure is the alternative to work, which means that wages must be paid or promised in order to induce workers to give up part of it. In this view, though desired by workers, leisure is not properly a consumption good and in particular is not considered part of national income (or output). If leisure were regarded as a consumption good produced by means of labour, as Sraffa thought it should be, it would not be an alternative to work - as labour is employed in its production too - but rather to other consumption goods like socks and butter. The decision about leisure time, in Sraffa's words, 'is a matter of allotment of expenditure'.

Sraffa used a similar argument for abstinence too. He noted that even though the alternative to waiting is consuming, if a millionaire were not induced to invest his capital in productive enterprises, he would not buy 'an enormous amount of food and proceed forthwith to eat a million worth of steaks and chops' but instead buy '“consumers' capital goods", such as motorcars, jewels, pictures, parks, etc.' What he would consume is therefore the annual services of these durable goods. As a result, if these services are included in national income, then the durable consumption goods must be regarded as capital goods, so that " "[w]aiting” becomes simply the choice made between two alternative investments' (D3/12/4:5(4)).

Sraffa draws three conclusions. First, all the services of durable goods in the capitalist's income and all leisure in the worker's income should be included in national income. Second, in accordance with the previous point, there are no alternatives to working and saving but simply different consumption goods, including leisure, and different forms of savings investment, including durable consumption goods (or consumers' capital goods). Finally, the theory of opportunity-costs, used as an explanation of the distribution variables, involves a vicious circle: the wage rate and the interest rate in each sector depend on the rates of the other sectors, but no mechanism of real determination is at work. Once leisure is understood as a consumption good obtained by diverting labour from the other activities, it is indistinguishable, form the point of view of the theory, from the other consumption goods. Accordingly, the wage rate cannot be seen as regulated by the quantity of labour employed in or diverted from the "leisure sector" because it is not different from the other productive sectors and

\footnotetext{
${ }^{40}$ In this view, land rent should not be considered as part of cost because the landlord has no alternative to using land in production. As Sraffa noted (D3/12/4:5(2)), in that theory 'only the landlord has no alternative use, therefore no inducement is required because he makes no sacrifice, and, therefore "rent does not enter into cost of production".' See also D3/12/7:18.
} 
therefore it cannot have a special power in the wage rate determination. In the same way, the investment of capital in durable consumption goods cannot play a role in interest rate determination which is different from all the other possible investments.

Concluding, according to Sraffa, it was by leaving leisure and the services of durable consumption goods outside the national output that this circularity was hidden, giving the false impression that the wage rate and the rate of interest could depend upon the disutility of working and saving.

\section{Physical cost vs psychological cost}

Once the cost is understood as what induces workers and capitalists to take part in the production processes, the dramatic difference versus the conception of physical cost adopted by Petty and the Physiocrats emerges quite clearly. The physical cost is made up of the commodities necessary for production, which are objectively determined and actually employed if the process is to take place, and can therefore be directly observed and measured. Conversely, what induces workers and savers to take part in production instead rests on psychological considerations and can take the form of the promise of commodities to be delivered at the end of the process.

This last remark underlies Sraffa's methodological criticisms of the neoclassical standpoint. Since cost can be regarded, in a certain sense, as the 'cause' of output, Sraffa raises the following objection:

\section{Physical costs}

Another very important difference between physical costs and psychic costs (besides enabling and inducing - rather, deriving from it) is that the former have to be paid (i.e. borne by somebody) before the beginning of production, since they must "enable" and they have actually to be destroyed in the course of production; the latter have to be paid (or distributed) after production has been made, they are simply a way of distributing the surplus, and this cannot be distributed before it exists, i.e. at the end of the period; if it has to induce only, at the beginning it is sufficient a promise, and at the end there is only legal obligation to fulfil it, but no material physical necessity, as in the case of enabling.

Now, the past cost can be a cause, but how can the future be a cause? (D3/12/10:97)

The answer is given by Sraffa in an interesting paper in which he employed Aristotle's distinction between two different sorts of causes, 'efficient' and 'final', also giving a very suggestive example:

\section{Carrots. Efficient \& final causes}

"Efficient causes" are facts of the past that act on the present: "final causes" are facts of the future that act on the present. The existence of the latter is at the best dubious and they are better called "illusions".

The classical $\mathrm{P}\{$ olitical $\} \mathrm{E}\{$ conomy $\}$ dealt only with the first sort of causes, i.e. of "material things" that have existed in the past. Modern economics deals with the second class, i.e. hopes for the future, such as utility, abstinence, disutility, etc.; these things, it must be noticed, refer only to the foreseeing of future acts. The economists have noticed 
this point; and have tackled the question whether it is the utility I shall actually get in the future through consumption that determines my demand price, or whether it is that very different thing - the utility I now imagine that I shall get in the future. Thus, $\mathrm{P}\{$ olitical $\} \mathrm{E}\{$ conomy $\}$ was a science of things, Economics is a science of illusions.

Example. Carrots are necessary if we want a donkey to work. But there are two sorts of carrots: those which we must have given to it before in order to enable it to work (otherwise it would be dead) and those you must show to it and promise to it in order to induce it to work.

There is a great difference between the two:

The first is a definite number or weight of real carrots, determined by physiological conditions, and - since they have been actually consumed, it has been possible to weigh them and to know exactly to the ounce their quantity: no tricks can be plaid about them.

The others are different. They needn't even be real carrots, - it may be a mashed paper carrot, rubbed against real carrots to take up the smell, which we simply show to the donkey, or it may be a stick, or it may be that at the end of its working day we fulfil our promise and give it its evening ration of carrots. But I suggest that we don't do this \{i.e. using mashed paper carrots \} because we are honest or because we don't want to damage our credit with the donkey, but simply because we want to enable it to work tomorrow.

Now, Economics deals with mashed paper carrots and whips, $\mathrm{P}\{$ olitical $\} \mathrm{E}\{$ conomy $\}$ dealt with real carrots. (D3/12/10:61, emphasis in the original)

In this extremely interesting paper, Sraffa thus outlined the difference between political economy and economics by means of the distinction between efficient and final causes. And since efficient causes alone - as maintained by Bacon, Spinoza and Descartes in particular - are to be taken into consideration in scientific investigations, final causes being instead regarded as fictions, he concluded that political economy alone deals with 'material things', namely the real working of actual phenomena, while economics deals with 'illusions'.

The carrots inducing the donkey to work can 'be mashed paper carrot, rubbed against real carrots to take up the smell, which we simply show to the donkey' and, at the end of the working day, we can decide whether to fulfil our promise, and give the donkey a ration of real carrots, or not. Conversely, with the means which enable the production, i.e. with the physical costs, no trick is possible because they are necessary and actually consumed. ${ }^{41}$ That also brings about the possibility of their observation and objective measurement. The difference is crystal clear.

\footnotetext{
${ }^{41}$ The same point was also expressed by Sraffa in a manuscript of November 1927:

Cost is means not inducement.

The possibility to produce depends upon the absolute real size of the remuneration: there is no trick possible, it is a physical material necessity. The willingness to produce depends upon the way in which payment is made: time wages or piece wages, premiums etc (which can be deducted from initial wage, so as to make the total wage equal to physical necessaries), payment conditional upon delivery of the goods (Robertson, in Economica) etc. It is a psychological necessity only, and can be overcome by tricks, cheating, etc. (D3/12/11:98, emphasis in the original).
} 


\section{8. 'What has happened then?'}

In the previous sections we followed Sraffa's analysis as to the fundamental steps in the history of the concept of cost, from Petty to the neoclassical authors. As Sraffa pointed out, rather than an evolution, there was actually a degeneration of the notion of cost which corresponded to a radical transformation of the theory of value and distribution and, therefore, of a fundamental part of economic science. Accordingly, the science itself, to stress this transformation, changed its name, from Political Economy to Economics, so as to emphasise the role played by the analytical arguments.

As seen in section 5, Sraffa, thanks to the reconstruction we have tried to outline here, was able to prove that - despite Marshall's and Whitaker's attempts at pointing to Smith and Ricardo as alleged precursors of the new idea of cost - the old theory was not embedded in but rather submerged by the advent of the new one. Now, the question is: what determined this change?

\section{Metaphysics}

In this theory it will be thought that the important part is the analytical and constructive. ${ }^{42}$ The significance of the historical side will be missed. And yet, this is the truly important, that which gives us a real insight into the mystery of human mind and understanding, into the deep unknown relations of individuals between themselves and between the individual and society, (the social, or rather the class mind).

It is terrific to contemplate the abysmal gulf of incomprehension that has opened itself between us and the classical economists. Only one century separates us from them: ${ }^{43}$ how can we imagine to understand the Greeks and the Romans $?^{44}$ The classical economists said things which were perfectly true, even according to our standards of truth: they expressed them very clearly, in terse and unambiguous language, as is proved by the fact that they perfectly understood each other. We don't understand a word of what they said: has their language been lost? Obviously not, as the English of Adam Smith is what people talk to-day in this country. What has happened then? (D3/12/4:14)

Therefore, the change brought about by the rise of neoclassical theory is far deeper and more dangerous than the simple degeneration of the notion of cost. It actually implied the adoption of a different view regarding the analysis of value and distribution. It suggested 'that the important part is the analytical and constructive', but what is truly important is instead the understanding, by means of the historical analysis, of the 'relations of individuals between themselves and between the individual and society'. And the change of perspective created an 'abysmal gulf of incomprehension' between

\footnotetext{
42 \{Sraffa's footnote: \} This is merely a toy, an intellectual gymnastic, which may give us some pleasure, because it suits our habit: it clears up some relations, but tells nothing about the nature of things: now, the relations between things obviously don't exist, they are merely a creation of our minds: do the things themselves exist, or are they merely our imaginations? This is the mystery on which no theory [can (or has ever been able, at least)] throw any light: nor does the present one. It is merely something comparable to a cigarette of the mind - or rather a dose of morphine.

${ }^{43}$ \{Sraffa's footnote: $\}$ I say a century: but even $1 / 2$ a century after, in 1870 , they did not understood it. And during the preceding century an obscure process of "disunderstanding" had been going on.

${ }^{44}$ \{Sraffa's footnote:\} Or rather, the extraordinary thing is that we do understand, since we find them perfect, Roman law and Greek philosophy.
} 
modern and classical economists. Since it was not a problem of language, Sraffa rhetorically wondered what had happened then.

The answer is provided by Sraffa in the last part of the following manuscript, in which he connects historical and social phenomena with the 'degeneration' of the theory.

Degeneration of cost \& value

A. Smith \& Ricardo, \& Marx indeed began to corrupt the old idea of cost, - from food to labour. But their notion was still near enough to be in many cases equivalent.

The decomposition went on at a terrific speed from 1820 to 1870: Senior's abstinence and Mill's mess of the whole thing. Cairnes brought it to the final stage "sacrifice" $\{\ldots\}$.

Simultaneously a much bigger step was taken in the process of shifting the basis of value from physical to psychical processes: Jevons, Menger, Walras.

This was an enormous breach with the tradition of Pol\{itical $\} \mathrm{E}\{$ conomy $\}$; in fact, this has meant the destruction of the classical $\mathrm{P}\{$ olitical $\} \mathrm{E}$ \{conomy $\}$ and the substitution for it, under the old name, of the Calculus of Pleasure \& Pain (Hedonistic). ${ }^{45}$

When the Jevonsians turned back to write their own history, they found with pride (it ought to have been with dismal) that they had no forerunners amongst $\mathrm{P}\{$ olitical $\}$ $\mathrm{E}\{$ conomists\}; their forerunners were mainly two or three cranks, an engineer Dupuit, a mathem\{atician\} Cournot, a Prussian Civil Servant Gossen, who had only cultivated $\mathrm{P}\{$ olitical $\} \mathrm{E}\{$ conomy $\}$ as a hobby. ${ }^{46}$

They had not the slightest knowledge of the works of the Classical economists. They drew it out of their fancy. In fact, no competent $\mathrm{P}\{$ olitical $\} \mathrm{E}\{$ cono $\}$ mist, with a conscience of his tradition, would have degnato to entertain those views.

What had happened in the meantime, to change so much the mind of the economists, and induce them to scrap all that had been done up to that time? $\{\ldots\}$

Socialism has been the cause of all this. In fact, classical $\mathrm{P}\{$ olitical $\} \mathrm{E}\{$ economy with its surplus to be arbitrarily divided, leads straight to Socialism. When after the death of Ricardo the first timid attempts of using socialistically his Theory of value were made $\{\ldots\}$, Senior \& Mill \& Cairnes rallied to the defence by making cost psychological.

But when the mass attack of Marx, and the threat of the rampant International and the Paris Commune came, a much more drastic defence was called for: not only sacrifice, but utility, - and simultaneously $\mathrm{J}\{$ evons $\} \mathrm{M}$ \{enger $\} \mathrm{W}$ \{alras $\}$ and their success. The classical economy was becoming too dangerous as a whole, it had to be scrapped bodily. It was a burning house which threatened to set to fire the whole structure and foundations of capitalist society - it was forthwith removed. (D3/12/4:2(1,2))

45 \{Sraffa's footnote:\} It is unfortunate that so much time has been taken to change the name of $\mathrm{P}\{$ olitical $\} \mathrm{E}\{$ economy $\}$ into Economics: but it is appropriate: it marks the cleavage, or rather the abyss, between the two.

46 Sraffa's footnote: $\}$ I do not mean by this that cranks can never find new theories: on the contrary, when a big breach with tradition is required, their intervention is usually necessary. What I mean to prove is that there has actually been a breach with tradition, and the intervention of the cranks is an element of the evidence; and that Marshall's attempt to bridge over the cleavage and establish a continuity in the tradition is futile and misguided. 
In section 4 it was seen that, after Ricardo's death, the labour theory of value was improperly used by the Ricardian socialists for political aims. A misunderstanding about the meaning and the role of the labour-value, as well as some ambiguities in the claims of the classical economists, led them to the naïve statement that since labour is the cause of the value of the entire product, then wages must take the entire (net) income. Therefore, when Jevons developed a theory of value grounded on marginal utility, he made explicit his intention to contrast the point of view, which he attributed to the alleged 'Ricardo-Mill school', according to which labour is the cause of value. Even the initial critical reaction to Marx's theory was formulated by neoclassical authors $^{47}$ in Jevons' terms, namely as if the fundamental point at issue was whether labour or (marginal) utility is the ultimate cause of value. ${ }^{48}$

Sraffa, on the contrary, grasped the matter in the right way. First, as seen in sections 3 and 4 following on from his reconstruction, Ricardo and Marx, notwithstanding some ambiguous passages, used labour primarily as a measure of the cost. The 'mystical' or 'metaphysical' conception of labour was instead the result of a misunderstanding, a sort of side effect which did not have a real role in their arguments. Second, as emerges from the manuscript cited above, Sraffa understood precisely what the central point is. He did not follow the Ricardian socialists and the 'Jevonians', but rightly grasped that it is the 'surplus to be arbitrarily divided' - and not the labour theory of value - that 'leads straight to Socialism'.

\section{Conclusions}

In these pages we have followed Sraffa in his reconstruction of what he called the 'degeneration of the notion of cost'. It, according to Sraffa, passed through four different phases or conceptions, which can be summarised as follows:

- Physical cost or "food" (Petty and the Physiocrats)

- Labour-cost (Smith, Ricardo and Marx)

- Pain-cost or "sacrifice" (vulgar economists: Senior and Cairnes, and, in terms of 'disutility', early neoclassical theory: Marshall)

- Opportunity-cost or "inducement" (modern theory: Davenport, Cassell and Henderson).

\footnotetext{
${ }^{47}$ Cf. in particular Böhm-Bawerk (1890) and Wicksteed (1884).

${ }^{48}$ Following the convincing reconstruction of the early development of the marginalist school given by Campus (1987), this sort of reaction to the socialists' ideas was due, on the one hand, to the confused or even incorrect way in which many Ricardian socialists made their case. On the other hand, it reflected 'the impasse of the marginalist theory of distribution at that time' (Campus 1987, pp. 11-12). More precisely, without a theory of distribution coordinated with their theory of value, the marginalist authors were prompted to follow a line of criticism "of an "esoteric" nature, i.e. that of simply contrasting the utility theory with the labour theory of value' (p. 12).

It was thus with Marshall's Principles - leaving aside Walras' Elements, which did not have a great impact at that time - that the marginalist theory arrived at a first solution of the problem.
} 
Thanks to this analysis of the evolution of the notion of cost, as we have tried to show, Sraffa was able to distinguish two different approaches to value and distribution. There is, on the one hand, what Sraffa considered the 'right notion of cost', the one adopted by Petty and the French Physiocrats, which arrived then, although measured in terms of labour, at the classical economists and Marx. On the other hand, there is the 'modern theory' and the notions of pain-cost and opportunity-cost. While the first notion is physically and objectively measurable, being the cost constituted by what is necessary in order to enable the production process to take place, the last notions of cost depend on psychological elements and the measurement - at least outside the partial equilibrium approach - may entail the logical difficulties highlighted by Sraffa (cf. in particular sections 2, 6 and 7).

Therefore, as Sraffa wrote, there was 'an enormous breach with tradition of Political Economy', so that 'Marshall's attempt to bridge over the cleavage and establish a continuity in the tradition', or even to reconcile Jevons with Ricardo, is deemed by Sraffa as 'futile and misguided.' Having been developed as a 'conscious reply' 49 to the socialist implications of the classical political economy, the neoclassical theory should necessarily be, and in fact is, appreciably different from the latter. The classical theory was not embodied in the new one, as Marshall ably tried to put it, but rather was 'submerged and forgotten since the advent of the "marginal" method' (Sraffa 1960, p.v).

\section{Acknowledgements}

I must first of all express my gratitude to the late Pierangelo Garegnani, under whose guidance I embarked some years ago on the study of the material discussed here. I also thank Antonietta Campus, Christian Gehrke, Heinz D. Kurz, Attilio Trezzini and the other economists involved in the project for the publication of Sraffa's manuscripts for fruitful exchanges of ideas.

I am most grateful to Jonathan Smith and the staff of the Wren Library for all the help received in the consultation of Sraffa's manuscripts and books.

Needless to say, the ideas put forward here are entirely my own and I alone am responsible for any errors or shortcomings.

\section{References}

Böhm-Bawerk, E. (1890). Capital and Interest: a Critical History of Economical Theory. London: Macmillan.

Böhm-Bawerk, E. (1894). The ultimate standard of value. Annals of the American Academy of Political and Social Science, 1-60.

\footnotetext{
${ }^{49}$ In a passage Sraffa copied (D3/12/11:8), J.M. Clark (1924, p. 83) noted that, referring to Fetter's article (1923), the development of the marginal-subjective doctrine was 'a conscious reply to Marx.'
} 
Bye, R. (1924). Some recent developments of economic theory. In: R.G. Tugwell (ed.), The Trend of Economics. New York: Alfred Knopf.

Campus, A. (1987). Notes on Cost and Price: Malthus and the Marginal Theory. Political Economy - Studies in the Surplus Approach, 3(1), 3-17.

Campus, A. (2000). Scontri e confronti tra teorie alternative del valore. Marshall e la controversia costo-utilità. In: M. Pivetti (ed.), Piero Sraffa. Contributi per una biografia intellettuale. Roma: Carocci.

Cannan, E. (1893). A History of the Theories of Production and Distribution in English Political Economy from 1776 to 1848. London: Percival and Co.

Clark, J.B. (1893). The ultimate standard of value. Publications of the American Economic Association, 8(1), 82-87.

Clark, J.M. (1924). The socializing of theoretical economics. In: R.G. Tugwell (ed.), The Trend of Economics. New York: Alfred Knopf.

De Vivo, G. (2001). Some notes on Sraffa Papers. In: T. Cozzi and R. Marchionatti (eds.), Piero Sraffa's Political Economy. A centenary estimate. London and New York: Routledge.

Fetter, F.A. (1923). Value and the Larger Economics. The Journal of Political Economy, 31(5), 587-605.

Garegnani, P. (1998). Sui manoscritti di Piero Sraffa. Rivista Italiana degli Economisti, $3(1), 151-56$.

Garegnani, P. (2004). Di una svolta nella posizione teorica e nella interpretazione dei classici in Sraffa nei tardi anni 20. In: Atti dei Convegni Lincei n. 200. Roma: Accademia Nazionale dei Lincei.

Garegnani, P. (2005). On a turning point in Sraffa's theoretical and interpretative position in the late 1920s. The European Journal of the History of Economic Thought, 12(3), 453-92.

Henderson, H. (1921). Supply and Demand. London/Cambridge: Nisbet/Cambridge University Press.

Jevons, W.S. (1888). The Theory of Political Economy, third edition. London: Macmillan.

Kurz, H.D. (1998). Against the current: Sraffa's unpublished manuscripts and the history of economic thought. The European Journal of the History of Economic Thought, 5(3), 437-451.

Kurz, H.D. (2003). The surplus interpretation of the classical economists. In: J.E. Biddle, J.B. Davis, W.J. Samuels (eds.), The Blackwell Companion to the History of Economic Thought. Oxford: Blackwell Publishers. 
Kurz, H.D. (2006). The agents of production are the commodities themselves. On the classical theory of production, distribution and value. Structural Change and Economic Dynamics, 17(1), 1-26.

Kurz, H.D. and Salvadori, N. (2005). Representing the Production and Circulation of Commodities in Material Terms: On Sraffa's Objectivism. Review of Political Economy, 17(3), 69-97.

Kurz, H.D. and Salvadori, N. (2006). Removing an 'insuperable obstacle' in the way of an objectivist analysis: Sraffa's attempts at fixed capital. The European Journal of the History of Economic Thought, 12(3), 493-523.

Marcuzzo, M.C. (2001). Sraffa and Cambridge economics, 1928-1931. In: T. Cozzi and R. Marchionatti (eds.), Piero Sraffa's Political Economy. A centenary estimate. London and New York: Routledge.

Marshall, A. (1920). Principles of Economics: an introductory volume. London: Macmillan.

Marshall, A. (1925). Memorials of Alfred Marshall, edited by A.C. Pigou. London: Macmillan.

Marx, K. (1872-1875). Le Capital, traduction de M. J. Roy entièrement revisée par l'auteur. Paris: Maurice Lachatre.

Marx, K. (1900-1902). Le Capital: critique d'économie politique, livres II et III (2 tomes), traduit à l'Institut des Sciences Sociales de Bruxelles. Paris: V. Giard \& E. Brière.

Marx, K. (1924). Histoire des doctrines économiques, tomes I-VIII, publiée par Karl Kautsky, traduit par J. Molitor. Paris: Alfred Costes.

Marx, K. (1961-1962). Capital, 3 vols. Moscow: Foreign Languages Publishing House.

Pasinetti, L.L. (2001). Continuity and change in Sraffa's thought: an archival excursus. In: T. Cozzi and R. Marchionatti (eds.), Piero Sraffa's Political Economy. A centenary estimate. London and New York: Routledge.

Ricardo, D. (1888). The Works of David Ricardo. With a Notice of the Life and Writings of the Author, edited by J.R. McCulloch. London: John Murray.

Ricardo, D. (1951-73). The Works and Correspondence of David Ricardo, 11 vols, edited by P. Sraffa with the collaboration of M.H. Dobb. Cambridge: Cambridge University Press.

Signorino, R. (2005). Piero Sraffa's lectures on the advanced theory of value 1928-31 and the rediscovery of the classical approach. Review of Political Economy, 17(3), 359-380.

Sraffa, P. (1925). Sulle relazioni fra costo e quantità prodotta. Annali di Economia, 2, 277-328. 
Sraffa, P. (1926). The laws of returns under competitive conditions. The Economic Journal, 36(144), 535-550.

Sraffa, P. (1960). Production of Commodities by Means of Commodities. Cambridge: Cambridge University Press.

Whitaker, A.C. (1904). History and Criticism of the Labor Theory of Value in English Political Economy. New York: Columbia University Press.

Wicksteed, P.H. (1884). Das Kapital: a criticism. To-Day, 2, 388-409. 
Author contact information:

Saverio M. Fratini

Department of Economics

Roma Tre University

Via Silvio D'Amico, 77

00145 - Rome (Italy)

saveriomaria.fratini@uniroma3.it 